\title{
DEGRADATION OF THE PHOSPHOLIPIDS OF THE SERUM LIPOPROTEINS BY LEPTOSPIRAE
}

\author{
L. B. Kăsarov* and Laura Addamiano \\ Laboratori di Microbiologia, Istituto Superiore di Sanità, Roma, Italy
}

Plate XXI

\begin{abstract}
PhosPhOlipids appear to serve as important nutrient substrates for leptospirae.
\end{abstract}

Fulton and Spooner (1956) reported that the phospholipid fraction of blood serum supported the respiration of Leptospira icterohaemorrhagiae. Ivler (1960) found that the oxygen consumption of one saprophytic strain of leptospira was increased by the addition of lecithin to the culture medium. Johnson and Wilson (1960) showed that a crude lecithin fraction of egg yolk supported good growth of the serotype pomona and could replace rabbit serum in culture media for leptospirae, and Mifuchi, Hosoi and Yanagihara (1961) found that the serotypes canicola and australis could grow in a medium that contained phospholipid fractions of an alcoholic extract of egg yolk instead of rabbit serum. Very little is known about the enzymatic degradation of phospholipids by leptospirae, though some findings have been reported by Addamiano and Papa (1966).

Since they contain each of the major types of phospholipids, the lipoproteins of blood serum are very suitable substrates for use in investigations of the degradation of the phospholipids. The susceptibility of the serum phospholipids to degradation is also interesting because serum is the source of these compounds in culture media for leptospirae.

\section{MATERIALS AND METHODS}

Organisms. Observations were made with both saprophytic and parasitic strains of leptospirae taken from the collection of the WHO/FAO Leptospira Reference Laboratory, which is kept in the Istituto Superiore di Sanita in Rome. The saprophytic strains were: serotype patoc strain Patoc 1, serotype são paulo strain São Paulo, serotype doberdo strain Doberdo 1, serotype basovizza strain Basovizza, strain Dindio (not yet classified), and strain AM20 (not yet classified). The parasitic strains were: strains Wijnberg and Ratto 67 of serotype copenhageni, strains RGA and Bianchi of serotype icterohaemorrhagiae, serotype ndambari strain Ndambari, serotype zanoni strain Zanoni, strains Pomona, Mezzano I, Simon, To-Cuminiana and Monjakov DVB of serotype pomona, strains Moskva V, Mallersdorf, Vitulina and RM2 of serotype grippotyphosa, serotype bataviae strain Pavia 1, and serotype djatzi strain HL26. Korthof's medium, as modified by Babudieri (1961), in amounts of $20 \mathrm{ml}$ was used for the cultivation of the leptospirae. Well-grown whole cultures, incubated for 10,20 and 30 days at $30^{\circ} \mathrm{C}$, and checked for absence of bacterial contamination, were used in the tests for degradation of phospholipids.

Serum. Fresh rabbit serum was used. It was stored at $4^{\circ} \mathrm{C}$ for $96 \mathrm{hr}$ and then filtered through a sterilised bacterial glass filter G $5 \mathrm{~m}$ (Jena Glaswerk Schott \& Gen., Mainz) to remove chylomicrons.

Received 30 Sept. 1968; accepted 16 Nov. 1968.

* Research Institute of Epidemiology and Microbiology, Sofia, Bulgaria. Present address : Department of Microbiology, Hahnemann Medical College, Philadelphia, Pennsylvania, USA.

J. MED. MICROBIOL.-VOL. 2 (1969) 
Tests of the effect of leptospirae on the serum lipoproteins. Three $\mathrm{ml}$ of a well-grown whole culture was mixed with $1 \mathrm{ml}$ of rabbit serum. In controls $3 \mathrm{ml}$ of Korthof's medium was used instead of the leptospiral culture. Parallel tests were made with and without the addition of $\mathrm{CaCl}_{2}(0.02 \mathrm{~m}$ moles to $1 \mathrm{ml}$ of serum $)$ to the assay mixture. Korthof's medium as modified by Babudieri does not contain $\mathrm{CaCl}_{2}$. After the assay mixture had been incubated at $37^{\circ} \mathrm{C}$ for $1-4$ days the lipids were extracted from it. Before the extraction, a second examination for bacterial contamination was made.

Total lipid extract. The extraction was carried out by the method described by Kasărov and Addamiano (1969).

Thin-layer chromatography. Thin-layer chromatography was done on plates of silica-gel $\mathrm{G}$ containing 13 per cent. $\mathrm{CaSO}_{4} \cdot \frac{1}{2} \mathrm{H}_{2} \mathrm{O}$ (E. Merck, Darmstadt, Germany). The developing system for separating the phospholipids was chloroform-methanol-water, 65:25:4 (v/v/v) (Marinetti, 1962). Cephalin and choline-containing phospholipids were detected by means of the ninhydrin and Dragendorf's reagents and identified by comparison of their mobility with those of pure compounds, which were included in the same plate as standards (fig. 1). Small changes in the size and intensity of the spots were not taken into consideration.

Samples of pure lecithin, lysolecithin and sphingomyelin were obtained through the courtesy of Professor L. L. M. van Deenen, of the State University of Utrecht, Netherlands. Cephalin (DL- $\alpha$-phosphatidyl ethanolamine) was purchased from Nutritional Biochemicals Corporation, USA.

\section{RESULTS}

Saprophytic strains. The results of the chromatographic analysis showed that incubation of rabbit serum with a whole culture of the saprophytic strain Patoc 1, São Paulo, Doberdo 1, Basovizza, Dindio or AM20 for 24-72 hr at $37^{\circ} \mathrm{C}$ caused a complete disappearance of the lysolecithin from the serum and a decrease in the amount of the lecithin. The cephalin was weakly degraded by the Basovizza and São Paulo strains, but not by other strains. In the tests in which calcium ions were added to the system there was a greater degradation or even a complete disappearance of lecithin and, in the tests with the strains Basovizza and São Paulo, of cephalin (fig. 2). The spot corresponding to sphingomyelin did not diminish appreciably in the tests with any saprophytic strain, whether or not calcium ions were added, and even when the incubation time was extended to $96 \mathrm{hr}$.

Parasitic strains. The parasitic strains Pomona, Simon, To-Cumiana, Mezzano I, Ndambari, Moskva V, Mallersdorf and Pavia 1 caused a complete disappearance of the lysolecithin and a large decrease or a complete disappearance of lecithin and sphingomyelin (fig. 3). Degradation of lecithin by the strain Pavia 1 was weak; it was too weak to be observed when the culture tested was more than 20-25 days old. Cephalin was degraded by the Simon and Ndambari strains only (fig. 3).

The parasitic strains RM2, Vitulina, Wjinberg, Bianchi 1, Ratto 67, RGA, Monjakov DVB, Zanoni and HL26 degraded lysolecithin only (fig. 3). They did not cause detectable degradation of lecithin, cephalin and sphingomyelin even when the period of incubation was extended to $96 \mathrm{hr}$. The parasitic strains gave the same results whether or not $\mathrm{CaCl}_{2}$ was added to the reaction mixture.

Conditions of degradation. The enzymatic activity of the cultures changed with their age. The activity of the saprophytic leptospirae reached a maximum 


\section{PHOSPHOLIPIDS AND LEPTOSPIRAE}

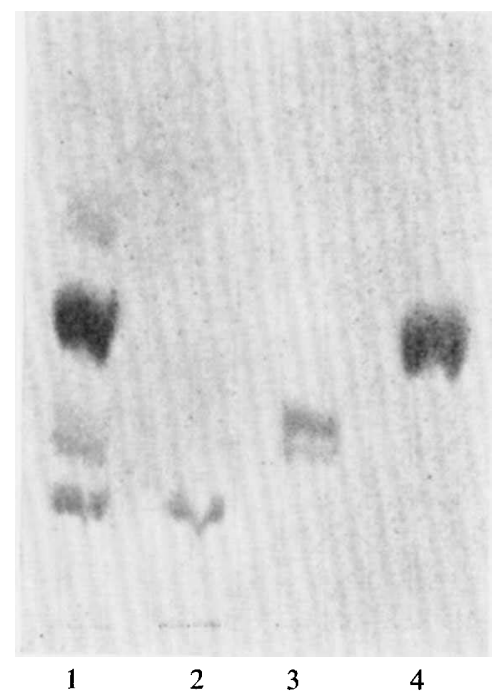

Fig. 1.-Thin-layer chromatography of an extract of the phospholipids from rabbit serum (1), pure lysolecithin (2), sphingomyelin (3), and lecithin (4).

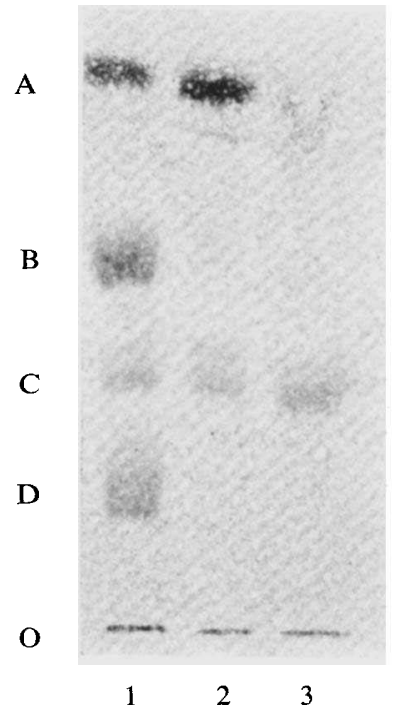

FIG. 2.-Thin-layer chromatography of the phospholipids extracted from rabbit serum after incubation for $72 \mathrm{hr}$ at $37^{\circ} \mathrm{C}$ with sterile Korthof medium (1), and after incubation with whole cultures of the saprophytic strains AM20 (2) and Basovizza (3). $\mathrm{A}=$ Cephalin; $\mathrm{B}=$ lecithin; $\mathrm{C}=$ sphingomyelin; $\mathrm{D}=$ lysolecithin; $\mathrm{O}=$ origin. $\mathrm{CaCl}_{2}$ was added to the test mixture.
A

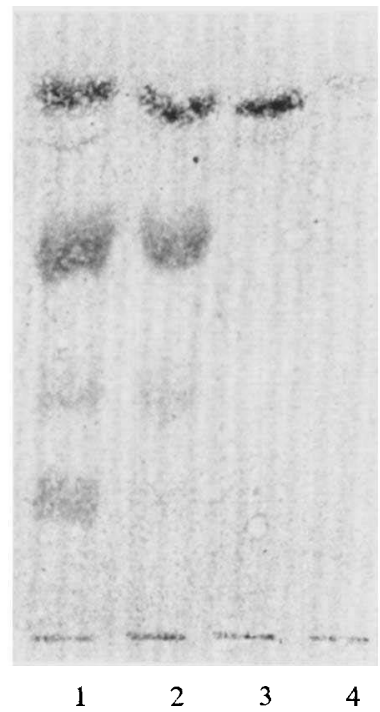

FIG. 3.- Thin-layer chromatography of the phospholipids extracted from rabbit serum after incubation for $72 \mathrm{hr}$ at $37^{\circ} \mathrm{C}$ with sterile Korthof medium (1), and after incubation with whole cultures of the parasitic strains Bianchi (2), Mallersdorf (3) and Simon (4). A = Cephalin; $\mathrm{B}=$ lecithin $; \quad \mathrm{C}=$ sphingomyelin $\quad \mathrm{D}=$ lysolecithin; $\mathrm{O}=$ origin. $\mathrm{CaCl}_{2}$ was added to the test mixture. 
after 10-20 day of incubation and that of the parasitic leptospirae reached a maximum after 15-25 days. Longer incubation periods led to a decrease of the enzymatic activity.

The velocity of degradation differed for the different phospholipids and the different strains. Lysolecithin was completely degraded within $4 \mathrm{hr}$ by all the saprophytic and parasitic strains. Degradation of sphingomyelin by the active parasitic strains was also rapid, and after $4-8 \mathrm{hr}$ the corresponding spot was one-third to one-quarter the size (area) of the control. Traces of sphingomyelin were observed for up to $18-36 \mathrm{hr}$. Degradation of lecithin by the parasitic strains and, in presence of calcium ions, by the saprophytic ones was noticeable only after $16-20 \mathrm{hr}$. After $24-36 \mathrm{hr}$ the corresponding spot was one-half to one-third the size of the control. Traces of lecithin were observed for up to $40-72 \mathrm{hr}$.

Requirement of calcium ions. To establish the requirement of calcium ions by the leptospiral enzymes that catalyse the degradation of phospholipids, tests were made in which Versene (EDTA), sodium citrate and sodium oxalate were added to the reacting mixtures. A concentration of $0.01 \mathrm{~m}$-moles of EDTA per $\mathrm{ml}$ of serum completely inhibited the degradation of lecithin, whether by the saprophytic or the parasitic leptospirae. Degradation of lecithin by the saprophytic strains was also completely inhibited by the addition of $0.004-0.012 \mathrm{~m}$-moles of sodium citrate or sodium oxalate per $\mathrm{ml}$ of serum. However, the addition of sodium citrate, even at a concentration as high as $0.2 \mathrm{~m}$-moles per $\mathrm{ml}$, and the addition of sodium oxalate, even at a concentration as high as $0.06 \mathrm{~m}$-moles per $\mathrm{ml}$, did not have any inhibitory effect on the degradation of lecithin by the parasitic strains.

The degradation of lysolecithin by the saprophytic and parasitic leptospirae and that of sphingomyelin by the parasitic strains were unaffected by EDTA, citrate and oxalate in the above-mentioned concentrations.

\section{Discussion}

Our results show that, on the basis of their ability to degrade the cholinecontaining phospholipids of the serum lipoproteins, the leptospirae can be divided into three groups: (A) strains degrading lecithin but not sphingomyelin, (B) strains degrading lecithin and sphingomyelin, and (C) strains degrading neither lecithin nor sphingomyelin. It is possible that strains of the third group have some ability to degrade lecithin and sphingomyelin, but bring about the reactions at a rate too low to be detected by our methods.

The saprophytic leptospirae (group A) seem to be characterised by the ability to degrade lecithin but not sphingomyelin. All our 6 strains behaved in this way. In view, however, of the small number of strains studied, we cannot say that failure to degrade lecithin is characteristic of all saprophytic leptospirae. The parasitic leptospirae were not uniform in their ability to degrade the choline-containing phospholipids. They were differentiated into the relatively active strains of group B and the relatively inactive ones of group C. Their enzymatic properties were not related to their antigenic character, and 
strains with different properties were present in the same serotype. For instance, 4 of the 5 pomona strains fell into group $\mathrm{B}$, but the fifth one belonged to group C. Two of the 4 grippotyphosa strains were in group B, but the other 2 were in group $\mathrm{C}$ (table).

TABLE

Degradation of the choline-containing phospholipids by leptospirae

\begin{tabular}{|c|c|c|c|c|c|}
\hline \multicolumn{3}{|c|}{ Leptospira organism } & \multicolumn{3}{|c|}{ Activity of organism in degrading } \\
\hline Group & Serotype & Strain & lysolecithin & lecithin & sphingomyelin \\
\hline A & $\begin{array}{l}\text { são paulo } \\
\text { patoc } \\
\text { doberdo } \\
\text { basovizza } \\
\text { (unclassified) } \\
\text { (unclassified) }\end{array}$ & $\begin{array}{l}\text { São Paulo } \\
\text { Patoc 1 } \\
\text { Doberdo } 1 \\
\text { Basovizza } \\
\text { Dindio } \\
\text { AM20 }\end{array}$ & $\begin{array}{l}+ \\
+ \\
+ \\
+ \\
+ \\
+\end{array}$ & $\begin{array}{l}+ \\
+ \\
+ \\
+ \\
+ \\
+\end{array}$ & $\begin{array}{l}- \\
- \\
- \\
- \\
-\end{array}$ \\
\hline B & $\begin{array}{l}\text { pomona } \\
\text { pomona } \\
\text { pomona } \\
\text { pomona } \\
\text { ndambari } \\
\text { grippotyphosa } \\
\text { grippotyphosa } \\
\text { bataviae }\end{array}$ & $\begin{array}{l}\text { Pomona } \\
\text { Simon } \\
\text { To-Cuminiana } \\
\text { Mezzano I } \\
\text { Ndambari } \\
\text { Moskva V } \\
\text { Mallersdorf } \\
\text { Pavia 1 }\end{array}$ & $\begin{array}{l}+ \\
+ \\
+ \\
+ \\
+ \\
+ \\
+ \\
+\end{array}$ & $\begin{array}{l}+ \\
+ \\
+ \\
+ \\
+ \\
+ \\
+ \\
+\end{array}$ & $\begin{array}{l}+ \\
+ \\
+ \\
+ \\
+ \\
+ \\
+ \\
+\end{array}$ \\
\hline $\mathrm{C}$ & $\begin{array}{l}\text { grippotyphosa } \\
\text { grippotyphosa } \\
\text { copenhageni } \\
\text { copenhageni } \\
\text { icterohaemorrhagiae } \\
\text { icterohaemorrhagiae } \\
\text { pomona } \\
\text { zanoni } \\
\text { djatzi }\end{array}$ & $\begin{array}{l}\text { RM2 } \\
\text { Vitulina } \\
\text { Wjinberg } \\
\text { Ratto 67 } \\
\text { Bianchi 1 } \\
\text { RGA } \\
\text { Monjakov DVB } \\
\text { Zanoni } \\
\text { HL26 }\end{array}$ & $\begin{array}{l}+ \\
+ \\
+ \\
+ \\
+ \\
+ \\
+ \\
+ \\
+\end{array}$ & $\begin{array}{l}= \\
= \\
= \\
= \\
=\end{array}$ & $\begin{array}{l}- \\
= \\
- \\
= \\
- \\
=\end{array}$ \\
\hline
\end{tabular}

All 4 main types of the phospholipids present in the serum lipoproteins were degraded by the specific leptospiral enzymes, though the different phospholipids were degraded with different velocities. Lysolecithin was the phospholipid most rapidly attacked; sphingomyelin was next most rapidly attacked, and cephalin and lecithin were degraded slowly and only after a longer period of incubation.

It is known that many enzymes that have phospholipids as substrates are activated by calcium ions. Such calcium-dependent enzymes include phospholipase A (phosphatide acylhydrolase, EC 3.1.1.4) from snake venoms (Long and Penny, 1957; Kates, 1960; Magee and Thompson, 1960) and bee venom (Neumann and Habermann, 1954), phospholipase C (phosphatidylcholine cholinephosphohydrolase, EC 3.1.4.3) from bacterial filtrates (Macfarlane and Knight, 1941), phospholipase D (phosphatidylcholine phosphatidohydrolase, EC 3.1.4.4) from cabbage and carrots (Davidson and Long, 1958; Einset 
and Clark, 1958; Weiss, Spiegel and Titus, 1959). For this reason the enzymatic activity of the leptospirae was investigated in parallel tests made with and without the addition of $\mathrm{CaCl}_{2}$ to the reacting mixtures. The results showed that the degradation of lecithin by the saprophytic leptospirae is activated by calcium ions. EDTA, sodium citrate and sodium oxalate completely inhibited this degradation. These inhibitors are believed to act by binding calcium ions. The fact that lecithin was degraded in tests made without the addition of calcium ions, though at a lower rate than in tests made with such an addition, suggests that the amount of free calcium ions in the serum and the amount of calcium ions bound to the serum lipoproteins are near to the optimum level for activation of the lecithin-degrading enzymes of the saprophytic strains.

In contrast, the degradation of lecithin by the parasitic leptospirae seems to be independent of the presence of calcium ions. The fact that this degradation is inhibited by $0.01 \mathrm{~m}$-moles of EDTA per $\mathrm{ml}$ of serum, but not by $0.2 \mathrm{~m}$-moles of sodium citrate or $0.06 \mathrm{~m}$-moles of sodium oxalate, suggests that the inhibitory action of EDTA does not depend upon a reduction in the concentration of calcium ions. This conclusion is supported by the fact that the addition of calcium ions in excess over EDTA did not restore the enzymatic degradation of lecithin by the parasitic leptospirae. A similar observation was made by Marinetti (1965) in his study of the action of phospholipase A on lipoproteins. Marinetti suggests that the inhibition may be due to a formation of an enzyme-Ca ${ }^{++}$-EDTA complex that is inactive and not dissociable. Such a complex did not appear to be formed in our experiments, since the addition of calcium ions in excess over EDTA restored the enzymatic degradation of lecithin by the saprophytic leptospirae.

Our results show that all the main types of phospholipids are susceptible to the action of specific leptospiral enzymes. The study of these enzymes is of interest not only because it may lead to a better understanding of the metabolism of the leptospirae but also because it may throw some light on the still unsolved question of the nature of the relation between metabolism and pathogenicity in this group of micro-organisms.

\section{SUMMARY}

The main types of phospholipids in serum lipoproteins, namely lysolecithin, lecithin, cephalin and sphingomyelin, are susceptible to degradation by specific enzymes of leptospirae. On the basis of their ability to attack lecithin and sphingomyelin the leptospirae can be divided into three groups: (A) strains degrading lecithin but not sphingomyelin, (B) strains degrading lecithin and sphingomyelin, and (C) strains degrading neither lecithin nor sphingomyelin. The saprophytic leptospirae belong to group A and the parasitic leptospirae to groups $\mathrm{B}$ and $\mathrm{C}$.

\section{REFERENCES}

Addamiano, Laura, and Papa, J. BABUDIERI, B. Davidson, Flora M., AND Long, C. EINSET, E., AND ClaRK, W. L.
1966. Annls Soc. belge Méd. trop., 46, 187. 1961. Bull. Wld Hlth Org., 24, 45.

1958. Biochem. J., 69, 458.

1958. J. Biol. Chem., 231, 703. 
Fulton, J. D., AND Spooner, D. F. 1956. Expl Parasit., 5, 154.

IVler, D. . . . . . . . 1960. Bact. Proc., p. 164.

Johnson, R. C., AND Wilson, J. B. . 1960. J. Bact., 80, 406.

Kasărov, L. B., AND AdDamiano, LAURA 1969. J. Med. Microbiol., 2, 165.

KATES, M. . . . . . . 1960. In Lipide metabolism, ed. by K. Bloch, New York, p. 188.

Long, C., ANd Penny, I. F. . 1957. Biochem. J., 65, 382.

MACFARLANE, MARJORIE G., AND KNIGHT, 1941. Ibid., 35, 884.

B. C. J. G.

Magee, W. L., AND Thompson, R. H. S. 1960. Ibid., 77, 526.

MaRINETTI, G. V. . . . . . . 1962. J. Lipid Res., 3, 1.

". • . 1965. Biochim. biophys. Acta, 98, 554.

Mifuchi, I., Hosor, M., AND YANaGI- 1961. Jap.J. Microbiol., 5, 215.

HARA, Y.

Neumann, W., and Habermann, E. 1954. Hoppe-Seyler's Z. physiol. Chem., 296,

Weiss, H., SpIEgel, H. E., AND Titus, E. 1959. Nature, Lond., 183, 1393. 